\title{
Ulisses e Dionísio. Comentário e questionamento sobre a obra de Nietzsche "Origens da Tragédia"*
}

\author{
Tristão de Alencar Araripe Júnior ${ }^{* *}$
}

Resumo: Artigo publicado em 1904, no Almanaque Garnier. Nele, o autor procura abordar a estética do jovem Nietzsche de um ponto de vista histórico genético bastante amplo. Com essa abordagem, faz alguns questionamentos acerca das ideias de apolínio e dionisíaco.

Palavras-chave: Nietzsche - dionisíaco - apolínio

Na sua obra Origens da tragédia Nietzsche explica a decadência grega e a de todo o Ocidente, pela morte do espírito dionisíaco.

O extermínio de Pã assinala justamente a débâcle da vida intensa, que houve no meio daquele povo privilegiado. Esse excídio completou-se na sistemática substituição dos grandes e misteriosos instintos da espécie humana pela razão, pela mesquinhez da análise, pela maiêutica socrática.

Eurípedes, acrescenta o autor de Assim falou Zaratustra, transportando o espectador, o povo, para a cena, onde originalmente só

\footnotetext{
* Artigo publicado no Almanaque do Garnier (A.B.G.) Rio de Janeiro, 1904, p. 193-194. Reeditado na Revista da Semana, no mês de Maio de 1913.

** Tristão de Alencar Araripe Júnior (1848-1911). Crítico, cronista e membro da Academia Brasileira de Letras.
} 
triunfam aqueles espíritos, nos símbolos de Ésquilo, e obrigando o antigo espectador ou o homem cotidiano a desempenhar os papeis na tragédia, foi o primeiro fator daquela decadência lutuosa.

A Grécia entrou na fase da franca miséria das faculdades trágicas; e não tardou que esse astuto chamado Ulisses, o conhecido tipo do graeculus, se generalizasse por toda a bacia do Mediterrâneo, preparando isso que se chama a civilização moderna, - o que importa o mesmo que dizer - a supressão do entusiasmo, como motor da existência, e do sonho apolínio como regime do espírito.

Começou a agir a reflexão, e o espírito de individuação prosseguindo através dos tempos, alagou a humanidade no nivelamento atrofiador do utilitarismo e da moral dos humildes.

Na opinião de Nietzsche, portanto, Ulisses, ou melhor, o gênio jônico é a causa eficiente do declive em que o mundo se perde, rolando indistintamente para o mal como os carneiros de Panúrgio para o abismo das ondas.

Nietzsche é, assim, coerente. Desde que a civilização vai completamente errada; e se o erro nasce, com efeito, do triunfo do gênio jônico sobre o paganismo helênico representado pelo Homero da Achilleida ou da Querela, pelo Ésquilo do Prometeu, e por Heráclito, não resta dúvida que outro remédio não haveria senão renovar, sob o ponto de vista moderno, a obra abordada de Juliano.

Por mais respeitável que seja a concepção do filósofo alemão, é licito fazer algumas interrogações.

Compreende-se o progresso, ainda mesmo nos seus termos absolutos, sem a disciplina jônica?

Seria preferencial a disciplina dórica?

Sem Ulisses acaso a terra teria sido suplantada, adquirida, conquistada?

Baco conquistou a Índia. A sua expansão seria suficiente para envolver a América, e os novos mundos?

Se Palas não houvesse subvertido as Eumenides, e criado o Areópago, o entusiasmo dionisíaco teria podido levantar, só por si, a Justiça, que acalmou a alma de Orestes? 
Que teria sido a cidade depois da vitória completa de Baco sobre o Universo?

Os vapores levantados até às nuvens por essa embriaguez da vida seria compatível com a existência filosófica de Bacon, de Newton, de Leibniz, de Kepler e Kant?

Rio, 30 de Dez. de 1902.

\begin{abstract}
Article published in 1905 in the Almanaque Garnier. In this article, the author seeks to address the young Nietzsche's aesthetics from an historical genetic large-scale point of view. With this approach, he asks questions about the ideias of Apollinean and the Dionysian.

Keywords: Nietzsche - Dionysian - Apollinean
\end{abstract}

